\title{
KUALITAS SOSIS DAGING SAPI YANG DIFORTIFIKASI DENGAN MINYAK IKAN KOD DAN MINYAK JAGUNG DAN DIPROSES MENGGUNAKAN METODE PEMASAKAN YANG BERBEDA
}

\author{
QUALITY OF BEEF SAUSAGES FORTIFIED WITH COD AND CORN OIL AND \\ PROCESSED WITH DIFFERENT COOKING METHODS
}

\author{
Rio Olympias Sujarwanta*, Edi Suryanto, Setiyono, Supadmo, dan Rusman \\ Fakultas Peternakan, Universitas Gadjah Mada, Yogyakarta, 55281
}

Submitted: 4 June 2015, Accepted: 14 September 2015

\section{INTISARI}

Penelitian ini bertujuan untuk mengetahui kualitas sosis daging sapi yang difortifikasi dengan minyak ikan kod dan minyak jagung dan diproses menggunakan metode pemasakan yang berbeda. Sosis dibuat dari daging sapi, minyak ikan kod, minyak jagung, tepung tapioka, susu skim, garam, merica, bawang putih, angkak, dan es, dengan rasio minyak ikan kod dan minyak jagung yaitu 2,9:7,1;2,4:7,6; dan $1,9: 8,1$. Semua bahan pembuatan sosis dicampur dan dimasukkan ke dalam selongsong sosis Sosis yang masih mentah dimasak menggunakan steaming dan vacuum steaming selama 30 menit. Sosis kemudian dianalisis komposisi kimia (kadar air, protein, dan lemak), kualitas fisik ( $\mathrm{pH}$, daya ikat air, dan keempukan), dan profil asam lemak (rasio asam lemak omega 3 dan omega 6). Data komposisi kimia dan kualitas fisik dianalisis secara statistika menggunakan analisis variansi (pola faktorial $=3$ faktor rasio minyak x 2 faktor metode pemasakan) dan perbedaan di antara rerata diuji dengan uji Duncan's new Multiple Ranges Test. Data profil asam lemak dianalisis secara deskriptif. Hasil penelitian menunjukkan bahwa rasio minyak ikan kod dan minyak jagung yang berbeda mempengaruhi kadar air, protein, $\mathrm{pH}$ daya ikat air, dan keempukan sosis $(\mathrm{P}<0,05)$. Vacuum steaming secara signifikan meningkatkan kadar air, protein, lemak, $\mathrm{pH}$, dan daya ikat air sosis $(\mathrm{P}<0,05)$. Sosis yang dimasak menggunakan vacuum steaming mengandung asam lemak omega 3 dan omega 6 yang lebih tinggi dibandingkan dengan sosis yang dimasak menggunakan steaming. Terdapat interaksi antara rasio minyak dengan metode pemasakan pada kadar air, protein, $\mathrm{pH}$, dan keempukan sosis $(\mathrm{P}<0,05)$. Kesimpulannya, fortifikasi sosis dengan minyak ikan kod dan minyak jagung pada rasio 2,4 : 7,6 dan diproses dengan vacuum steaming menghasilkan kualitas sosis yang paling baik.

(Kata kunci: Komposisi kimia, Kualitas fisik, Minyak ikan kod, Minyak jagung, Sosis, Vacuum steaming)

\begin{abstract}
This study was conducted to find out quality of beef sausages fortified with cod and corn oil and processed with different cooking methods. The sausages were made of beef, cod oil, corn oil, tapioca flour, skimmed milk, salt, pepper, garlic, angkak, and ice, with the ratio of cod oil and corn oil of 2.9 : 7.1; 2.4 : 7.6; and $1.9: 8.1$. All sausages ingredients were mixed and then filled in the casing. The raw sausages were cooked using steaming and vacuum steaming for 30 minutes. The sausages were then analyzed for chemical composition (moisture, protein, and fat contents), physical quality ( $\mathrm{pH}$, water holding capacity, and tenderness), and fatty acids profile (omega 3 and omega 6 ratio). The data of chemical composition and physical quality were analyzed statistically using analysis of variance (factorial pattern $=3$ factors of oil ratio $\times 2$ factors of cooking method) and the differences between means were tested by Duncan's new Multiple Ranges Test. The data of fatty acids profile were analyzed descriptively. The results showed that the different ratio of cod and corn oils affected the moisture content, protein content, $\mathrm{pH}$, and water holding capacity of sausages $(P<0.05)$. Vacuum steaming increased significantly the moisture content, protein content, fat content, $\mathrm{pH}$, and water holding capacity of sausages $(P<0.05)$. The sausages cooked with vacuum steaming contained higher omega 3 and omega 6 than that of steaming sausages. There were interactions between oil ratio and cooking methods on the moisture content, protein content, $\mathrm{pH}$, and tenderness of sausages $(P<0.05)$. In conclusion, fortification of sausages with cod and corn oil at $2.4: 7.6$ ratio and cooked with vacuum steaming resulting the best quality of sausages.
\end{abstract}

(Key words: Chemical composition, Cod oil, Corn oil, Physical quality, Sausages, Vacuum steaming)

\footnotetext{
${ }^{*}$ Korespondensi (corresponding author):

Telp. +62 856154 2868, E-mail: rioolympias@gmail.com
} 


\section{Pendahuluan}

Penyakit degeneratif seperti jantung koroner dan stroke pada saat ini tendensinya cenderung semakin meningkat. Selain dapat menyebabkan kematian, penderitanya pun mengalami penurunan produktivitas, dan belum lagi harus membayar biaya pengobatan yang relatif mahal. Pada tahun 2008 jumlah kematian yang disebabkan oleh penyakit kardiovaskular di Indonesia mencapai 39\% (Anonim, 2012). Salah satu faktor yang diduga menjadi penyebabnya adalah pola makan berupa makanan siap saji yang semakin banyak dikonsumsi. Oleh karena itu bahan pangan yang dikonsumsi perlu lebih mendapatkan perhatian, di antaranya adalah bahan pangan yang mengandung lemak dan kolesterol seperti daging.

Daging mengandung lemak dan kolesterol yang kalau dikonsumsi berlebihan dapat berdampak negatif bagi kesehatan (Krummel, 2008; Setiyono, 2008). Pada sistem pemeliharaan secara penggemukan (feed lot), ternak mendapatkan pakan berupa konsentrat sehingga peningkatan berat badannya tinggi dan proporsi dagingnya pun lebih tinggi (Setiyono, 2008). Daging hasil sistem penggemukan (feed lot) biasanya mengandung proporsi lemak dan kolesterol yang tinggi. Hasil penelitan yang dilakukan oleh Setiyono (2008) menunjukkan bahwa daging sapi Peranakan Ongole yang dipelihara secara feedlot mempunyai kadar lemak yaitu sebesar $5,98 \%$ (otot Longissimus dorsi) dan 5,87\% (otot Biceps femoris) dan kolesterol sebesar $81,39 \mathrm{mg} / 100 \mathrm{~g}$ daging (otot Longissimus dorsi) dan $83,09 \mathrm{mg} / 100 \mathrm{~g}$ daging (otot Biceps femoris). Dalam rangka menyediakan daging yang lebih sehat maka diperlukan teknologi pengolahan daging, di antaranya melalui restrukturisasi daging. Salah satu bentuk produk daging proses yang sudah mengalami restrukturisasi adalah sosis.

Sosis adalah suatu produk makanan yang dibuat dari daging yang sudah digiling dan dihaluskan, ditambahkan dengan bumbu-bumbu, dan dimasukkan ke dalam selongsong (casing) untuk diolah lebih lanjut (Martin dan Garden, 2004). Pada pembuatan sosis dapat ditambahkan (fortifikasi) dengan berbagai macam minyak, misalnya minyak ikan kod dan minyak jagung. Lemak atau minyak berpengaruh dalam proses pengikatan (binding), reologi, dan penampilan struktural produk daging (Choi et al., 2009; Marchetti et al., 2013). KrisEtherton et al. (2002) cit. Zhang et al. (2010) menyatakan bahwa minyak ikan kod banyak mengandung eicosa pentaenoic acid (EPA) dan docosa hexaenoic acid (DHA), yang merupakan asam lemak omega 3 sebesar $0,13 \mathrm{~g} / \mathrm{g}$ minyak (ikan kod yang berasal dari lautan Pasifik) dan 0,24 g/g (ikan kod yang berasal dari lautan Atlantik), sedangkan minyak jagung banyak mengandung asam lemak linoleat yang merupakan asam lemak omega 6 yaitu rerata sebesar 48\% (SNI, 1998), sehingga kombinasi antara minyak ikan kod dan minyak jagung diharapkan dapat menghasilkan asam lemak omega 3 dan asam lemak omega 6 sosis dengan rasio yang ideal yaitu sebesar $1: 5$. Asam lemak omega 3 dan asam lemak omega 6 dengan rasio yang ideal telah diketahui dapat menurunkan kadar kolesterol darah (Setiyono, 2008; Elmadfa dan Kornsteiner, 2009; Anonim, 2015).

Pengolahan bahan pangan menggunakan pemanasan di samping mempunyai pengaruh yang positif tetapi juga mempunyai pengaruh yang negatif. Pengaruh yang positif yaitu untuk preservasi pangan dengan memberikan efek destruksi panas (pasteurisasi) yang mampu membunuh mikrobia dan menginaktifasi enzim yang terdapat pada bahan pangan tersebut sehingga memperpanjang lama simpan, mendapatkan sosis yang teksturnya kompak dengan adanya koagulasi protein, dan mempertegas warna (Muchtadi dan Ayustaningwarno, 2010). Pengaruh yang negatif yaitu perubahan yang dapat terjadi khususnya pada asam lemak tidak jenuh ganda/jamak selama proses pemanasan pada temperatur yang tinggi antara lain : 1). Ikatan ganda dapat diubah menjadi ikatan tunggal; 2). Lokasi ikatan rangkap rantai asam lemak tidak jenuh dapat bergerak naik; dan 3). Konfigurasi ikatan ganda dapat diubah ke trans (Valenzuela dan Morgado, 1999). Untuk mengurangi pengaruh yang negatif diperlukan metode pemasakan yang tepat dan selama ini banyak digunakan metode pemasakan steaming secara konvensional untuk mematangkan sosis. Pemasakan steaming secara konvensional yaitu pemanasan bahan pangan menggunakan uap air panas atau mendidih (tekanan $1 \mathrm{~atm}$ atau $76 \mathrm{~cm} \mathrm{Hg}$ ) dalam wadah tertutup (Mariscal dan Bouchon, 2008; Dueik et al., 2010). Alternatif metode pemasakan lain 
yang sedang dikembangkan untuk mematangkan sosis yaitu metode pemasakan steaming secara vakum. Pemasakan secara vakum yaitu pemasakan dengan kandungan oksigen $\left(\mathrm{O}_{2}\right)$ yang minimal atau bahkan tanpa kandungan oksigen $\left(\mathrm{O}_{2}\right)$ dengan tekanan yang rendah (<76 cm $\mathrm{Hg}$ ) sehingga dapat menurunkan titik didih air (Amany et al., 2012). Penggunaan metode pemasakan secara vakum mempunyai kelebihan yaitu sampel dipanaskan pada temperatur yang rendah, selain itu kandungan oksigen $\left(\mathrm{O}_{2}\right)$ yang minimal dapat menghambat terjadinya proses oksidasi lipid dan reaksi pencoklatan secara enzimatis sehingga warna dan kandungan nutrien sampel dapat tetap terjaga (Troncoso et al., 2009; Amany et al., 2012).

Sejauh ini belum banyak adanya upaya-upaya ataupun perhatian untuk menyediakan produk daging proses yang mengalami restrukturisasi yaitu sosis yang mempunyai komposisi kimia dan kualitas fisik sosis yang baik, rasio asam lemak omega 3 dan omega 6 yang ideal, serta macam dan rasio minyak serta metode pemasakan yang tepat belum diketahui. Penelitian ini bertujuan untuk mengetahui komposisi kimia, kualitas fisik, dan rasio asam lemak omega 3 dan omega 6 sosis daging sapi yang diformulasi dengan rasio minyak ikan kod dan minyak jagung yang berbeda dan diproses dengan metode pemasakan yang berbeda.

\section{Materi dan Metode}

\section{Materi}

Alat yang digunakan antara lain: pisau, dandang, baskom, timbangan digital, mesin penggiling (grinder), chopper, stuffer, kompor, panci, thermometer, alat vacuum cooking, gelas beaker, batang pengaduk, desikator, erlenmeyer, pipet, tabung kjeltec, buret, Soxhlet, $\mathrm{pH}$ meter, penetrometer, beban $35 \mathrm{~kg}$, plat kaca, dan alat kromatografi gas.

Bahan yang digunakan antara lain: daging sapi, minyak ikan kod, minyak jagung, tepung tapioka, susu skim, garam, merica, bawang putih, angkak, es, dan casing sosis. Bahan untuk pengujian meliputi kertas saring, $\mathrm{NaOH} 40 \%, \mathrm{H}_{2} \mathrm{SO}_{4}, \mathrm{HCl} \quad 0,1 \mathrm{~N}$, indikator Brom Cresol Green (BCG)+Methylen Red (MR), tablet kjeltab, aquades, buffer, heksan, metanol, gas $\mathrm{N}_{2}$, dan metil ester.

\section{Metode}

Tiga macam rasio minyak ikan kod dan minyak jagung yaitu: $2,9: 7,1 ; 2,4: 7,6$; dan $1,9: 8,1$ didapatkan pada tahap prepenelitian. Pada tahap pre-penelitian meliputi analisis komposisi kimia dan profil asam lemak bahan-bahan yang digunakan dalam pembuatan sosis yaitu daging sapi, minyak ikan kod, minyak jagung, tepung tapioka, susu skim, merica, bawang putih, dan angkak. Berdasarkan komposisi bahanbahan tersebut dilakukan formulasi menggunakan software Microsoft Excel 2010 untuk menentukan rasio minyak ikan kod dan minyak jagung yang diduga dapat menghasilkan sosis dengan rasio asam lemak omega 3 dan omega 6 yang ideal yaitu $1: 5$.

\section{Pembuatan sosis}

Daging sapi yang telah dipotong kecilkecil dan dibersihkan dari jaringan ikat, kemudian digiling halus dengan menggunakan grinder. Daging yang telah digiling sebesar $62,5 \%$ dari total adonan, kemudian ditambahkan bahan pengikat (binder) yaitu susu skim (15\%). Adonan ditambahkan tepung tapioka sebagai bahan pengisi (filler). Kemudian adonan dibagi ke dalam tiga macam rasio minyak ikan kod dan minyak jagung (\%: \%) yaitu : $2,9: 7,1 ; 2,4: 7,6$; dan $1,9: 8,1$. Adonan ditambahkan garam $(1,5 \%)$, merica $(0,5 \%)$, bawang putih $(1,5 \%)$, dan angkak $(0,5 \%)$ sedikit demi sedikit sampai semua bahan tercampur merata. Adonan ditambahkan es $(6 \%)$ dan dihaluskan menggunakan chopper selama 5 menit, kemudian dimasukkan ke dalam casing (selongsong) sosis. Sosis diproses dengan metode pemasakan steaming pada temperatur $100^{\circ} \mathrm{C}$ selama 30 menit dan vacuum steaming pada temperatur $70^{\circ} \mathrm{C}$ (tekanan diatur konstan) selama 30 menit. Sosis kemudian diangkat dan dianginanginkan untuk pengujian selanjutnya. Ulangan dilakukan 3 kali untuk masingmasing perlakuan.

\section{Analisis}

Analisis komposisi kimia sosis meliputi kadar air diuji menggunakan metode AOAC (2005), kadar protein diuji menggunakan metode Kjeldahl (Sudarmadji et al., 1997), dan kadar lemak diuji menggunakan metode Soxhlet (AOAC, 2005). Analisis kualitas fisik sosis meliputi nilai $\mathrm{pH}$ sosis diuji menurut Bouton et al. (1971), daya ikat air sosis diuji menggunakan modifikasi metode Hamm 
(1986), dan keempukan sosis diuji menggunakan penetrometer menurut Candogan dan Kolsarici (2003). Analisis asam lemak omega 3 dan omega 6 sosis diuji meng-gunakan metode kromatografi gas (AOAC, 2005). Perhitungan rasio asam lemak omega 3 dengan omega 6 dilakukan secara matematik.

\section{Analisis data}

Data komposisi kimia dan kualitas fisik sosis dianalisis secara statistika menggunakan analisis variansi (pola faktorial $=3$ faktor rasio minyak $\times 2$ faktor metode pemasakan) dan perbedaan di antara rerata diuji dengan uji Duncan's new Multiple Ranges Test (Steel dan Torrie, 1993). Data rasio asam lemak omega 3 dan omega 6 sosis dianalisis secara deskriptif.

\section{Hasil dan Pembahasan}

\section{Komposisi kimia sosis}

Hasil uji komposisi kimia (kadar air, protein, dan lemak) sosis daging sapi yang diformulasi dengan tiga macam rasio minyak ikan kod dan minyak jagung yang berbeda dan diproses dengan dua metode pemasakan yang berbeda disajikan pada Tabel 1.

Kadar air. Metode pemasakan yang berbeda menunjukkan perbedaan yang nyata pada kadar air sosis $(P<0,05)$. Temperatur pemasakan yang lebih rendah pada vacuum steaming menyebabkan kadar air sosis lebih tinggi $(65,85 \pm 0,79 \%)$ dibandingkan dengan sosis yang dimasak secara steaming $(63,35 \pm 0,19 \%)$. Penurunan kadar air sosis ini menunjukkan air yang terikat di dalam sosis khususnya air yang terdapat pada permukaan sosis dan air yang tidak terikat di dalam sosis keluar. Pada pemasakan secara vakum terjadi proses depresurisasi atau pengurangan tekanan yang dapat mempertahankan kualitas mikrostruktur sosis pada permukaan sosis sehingga mencegah keluarnya air yang terdapat pada permukaan sosis. Selain karena transfer panas, hilangnya air dapat disebabkan juga oleh difusi panas. Pada temperatur pemanasan yang rendah difusi panas akan berjalan dengan lambat (Soeparno, 2005; Mariscal dan Bouchon, 2008; Dueik et al., 2010). Lebih lanjut dijelaskan bahwa pemasakan menyebabkan perubahan daya ikat air karena adanya solubilitas protein, suhu yang tinggi pada saat proses pemasakan akan dapat meningkatkan proses denaturasi protein dan menurunkan daya ikat air sehingga kadar airnya rendah. Temperatur pemasakan yang rendah pada vacuum steaming yaitu $70^{\circ} \mathrm{C}$ menyebabkan air yang keluar dari sosis lebih sedikit dibandingkan dengan air yang keluar dari sosis pada steaming.

Rasio minyak yang berbeda menunjukkan perbedaan yang nyata pada kadar air sosis $(P<0,05)$, semakin rendah rasio minyak ikan kod atau semakin tinggi rasio

Tabel 1. Komposisi kimia sosis yang diformulasi dengan rasio minyak ikan kod dan minyak jagung yang berbeda dan diproses dengan metode pemasakan yang berbeda

(chemical composition of sausages formulated with different ratio of cod oil and corn oil and processed with different cooking methods)

\begin{tabular}{|c|c|c|c|c|}
\hline \multirow[t]{2}{*}{ Variabel (variable) } & \multicolumn{3}{|c|}{$\begin{array}{c}\text { Rasio minyak ikan kod dan minyak jagung (ratio of } \\
\text { cod oil and corn oil) }\end{array}$} & \multirow[t]{2}{*}{$\begin{array}{l}\text { Rerata } \\
\text { (average) }\end{array}$} \\
\hline & $2,9: 7,1$ & $2,4: 7,6$ & $1,9: 8,1$ & \\
\hline \multicolumn{5}{|c|}{$\overline{\text { Kadar air (\%) (moisture content (\%)) }}$} \\
\hline Steaming & $63,13 \pm 0,02$ & $63,48 \pm 0,09$ & $63,45 \pm 0,15$ & $63,35 \pm 0,19^{p}$ \\
\hline Vacuum steaming & $66,82 \pm 0,13$ & $65,70 \pm 0,11$ & $65,02 \pm 0,02$ & $65,85 \pm 0,79 q$ \\
\hline Rerata (average) & $64,98 \pm 2,02^{c}$ & $64,59 \pm 1,22^{b}$ & $64,24 \pm 0,87^{a}$ & \\
\hline \multicolumn{5}{|c|}{ Kadar protein (\%) (protein content (\%)) } \\
\hline Steaming & $15,09 \pm 0,03$ & $14,99 \pm 0,10$ & $14,89 \pm 0,09$ & $14,99 \pm 0,11^{\mathrm{p}}$ \\
\hline Vacuum steaming & $17,01 \pm 0,04$ & $15,85 \pm 0,12$ & $16,65 \pm 0,07$ & $16,50 \pm 0,52^{q}$ \\
\hline Rerata (average) & $16,05 \pm 1,05^{c}$ & $15,42 \pm 0,48^{a}$ & $15,77 \pm 0,97^{b}$ & \\
\hline \multicolumn{5}{|c|}{ Kadar lemak (\%) (fat content (\%)) } \\
\hline Steaming & $8,57 \pm 0,24$ & $8,76 \pm 0,08$ & $8,60 \pm 0,90$ & $8,64 \pm 0,48^{p}$ \\
\hline Vacuum steaming & $11,08 \pm 0,05$ & $11,37 \pm 0,11$ & $11,62 \pm 0,16$ & $11,36 \pm 0,25^{q}$ \\
\hline Rerata (average) ${ }^{\text {ns }}$ & $9,83 \pm 1,38$ & $10,07 \pm 1,43$ & $10,11 \pm 1,75$ & \\
\hline & & & & \\
\hline Superskrip & 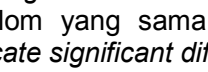 & njukkan & $\mathrm{ng}$ & \\
\hline
\end{tabular}


minyak jagung maka kadar air sosis semakin rendah. Wan et al. (2005) dan Setiyono (2008) menyatakan bahwa kadar air akan menyesuaikan dengan macam dan kadar lemak atau minyak yang ditambahkan di dalam produk daging restruktur serta kemampuan mengikat air oleh protein daging. Kadar air sosis hasil penelitian ini masih memenuhi Standar Nasional Indonesia (SNI) (1995).

Terdapat interaksi yang nyata antara metode pemasakan yang berbeda dengan rasio minyak yang berbeda pada kadar air sosis $(P<0,05)$. Temperatur pemasakan yang lebih rendah pada vacuum steaming dibandingkan steaming dan rasio minyak ikan kod yang semakin rendah atau rasio minyak jagung yang semakin tinggi diikuti dengan peningkatan kadar air sosis.

Kadar protein. Metode pemasakan yang berbeda menunjukkan perbedaan yang nyata pada kadar protein sosis $(P<0,05)$. Temperatur pemasakan yang lebih rendah pada vacuum steaming menyebabkan kadar protein sosis lebih tinggi $(16,50 \pm 0,52 \%)$ dibandingkan sosis yang dimasak menggunakan steaming $(14,99 \pm 0,11 \%)$. Hasil penelitian ini diduga karena temperatur vacuum steaming yang lebih rendah $\left(70^{\circ} \mathrm{C}\right)$ dibandingkan temperatur steaming $\left(100^{\circ} \mathrm{C}\right)$ berakibat pada sedikitnya proses denaturasi protein. Hasil penelitian sesuai dengan Widaningrum et al. (2008), yang menyatakan bahwa penggunaan pemasakan secara vakum menghasilkan kadar protein keripik buncis muda yang cukup tinggi.

Rasio minyak yang berbeda menunjukkan perbedaan yang nyata pada kadar protein sosis $(P<0,05)$. Hasil penelitian ini diduga karena minyak ikan kod dan minyak jagung yang digunakan sebagai bahan penyusun sosis mempunyai kadar nitrogen yang berbeda. Soeparno (2005) dan Setiyono (2008) menyatakan bahwa variasi kadar protein dipengaruhi oleh bahan-bahan penyusun produk daging restruktur. Kadar protein sosis hasil penelitian ini masih memenuhi Standar Nasional Indonesia (SNI) (1995).

Terdapat interaksi yang nyata antara metode pemasakan yang berbeda dengan perlakuan rasio minyak yang berbeda pada kadar protein sosis $(P<0,05)$. Temperatur pemasakan yang lebih rendah pada vacuum steaming dibandingkan dengan steaming dan rasio minyak ikan kod yang semakin tinggi atau rasio minyak jagung yang semakin rendah diikuti dengan peningkatan kadar protein sosis.

Kadar lemak. Metode pemasakan yang berbeda menunjukkan perbedaan yang nyata pada kadar lemak sosis $(P<0,05)$. Temperatur pemasakan yang lebih rendah pada vacuum steaming menyebabkan kadar lemak sosis $(11,36 \pm 0,25 \%)$ lebih tinggi dibandingkan sosis yang dimasak menggunakan steaming $(8,64 \pm 0,48 \%)$. Penurunan kadar lemak diduga karena lemak yang berada di dalam sosis keluar karena temperatur pemasakan yang lebih tinggi terutama pada steaming dibandingkan dengan vacuum steaming. Dueik et al. (2010) dan Amany et al. (2012) menyatakan bahwa semakin tinggi temperatur pemasakan akan menyebabkan suatu produk menjadi semakin porous dan emulsinya dapat pecah, hal ini menyebabkan kadar air dan kadar lemak menurun. Tarzi et al. (2011) dan Amany et al. (2012) menyatakan bahwa absennya udara selama pemasakan dapat menghambat proses oksidasi termasuk oksidasi lipid, reaksi pencoklatan secara enzimatis, oleh karena itu warna dan kandungan sampel dapat terlindungi. Saguy dan Dana (2003) dan Amany et al. (2012) menyatakan bahwa vacuum frying dapat mempertahankan kualitas minyak yang dipakai untuk menggoreng dan minyak yang ada di dalam produk.

Rasio minyak yang berbeda tidak menunjukkan perbedaan yang nyata pada kadar lemak sosis. Hal ini diduga karena minyak ikan kod dan minyak jagung yang digunakan sebagai bahan penyusun sosis mempunyai kadar lemak yang relatif sama, sehingga tidak menyebabkan perbedaan kadar lemak sosis pada masing-masing rasio minyak. Sheard et al. (1998); Wan et al. (2005); dan Setiyono (2008) menyatakan bahwa kadar lemak tergantung pada kadar lemak daging (macam daging) dan kadar lemak bahan yang ditambahkan dalam produk. Kadar lemak sosis hasil penelitian ini masih memenuhi Standar Nasional Indonesia (1995). Tidak terdapat interaksi yang nyata antara metode pemasakan yang berbeda dengan rasio minyak yang berbeda pada kadar lemak sosis.

\section{Kualitas fisik sosis}

Hasil uji kualitas fisik (nilai $\mathrm{pH}$, daya ikat air, dan keempukan) sosis daging sapi yang diformulasi dengan tiga macam rasio 
minyak ikan kod dan minyak jagung yang berbeda dan diproses dengan dua metode pemasakan yang berbeda disajikan pada Tabel 2.

Nilai pH. Metode pemasakan yang berbeda menunjukkan perbedaan yang nyata pada nilai $\mathrm{pH}$ sosis $(\mathrm{P}<0,05)$. Temperatur pemasakan yang lebih tinggi pada steaming menyebabkan nilai $\mathrm{pH}$ sosis $(6,13 \pm 0,08)$ lebih rendah dibandingkan nilai $\mathrm{pH}$ sosis yang dimasak menggunakan vacuum steaming $(6,52 \pm 0,17)$. Hasil penelitian ini diduga disebabkan temperatur pemasakan yang tinggi pada steaming mengurangi konsentrasi hidrogen di dalam sosis sehingga $\mathrm{pH}$ sosis menurun. White (1991); Melton et al. (1994); dan Amany et al. (2012) menyatakan bahwa selama proses pemasakan terjadi proses oksidasi minyak atau lemak menjadi hidroperoksida, alkohol, keton, aldehid, dan asam lemak bebas. Di antara produk oksidasi tersebut diduga ada yang bersifat asam yang dapat menyebabkan nilai $\mathrm{pH}$ menurun. Nilai $\mathrm{pH}$ sosis pada vacuum steaming lebih tinggi dibandingkan dengan nilai $\mathrm{pH}$ sosis yang dimasak menggunakan steaming, hal ini disebabkan karena selama vacuum steaming hanya sedikit terjadi proses oksidasi minyak atau lemak yang diduga dapat menurunkan nilai pH. Amany et al. (2012) menyatakan bahwa bilangan peroksida keripik kentang yang digoreng secara vakum (vacuum frying) menggunakan minyak biji bunga matahari lebih rendah dibandingkan yang digoreng secara konvensional.

Rasio minyak yang berbeda menunjukkan perbedaan yang nyata pada nilai $\mathrm{pH}$ sosis $(\mathrm{P}<0,05)$, semakin rendah rasio minyak ikan kod atau semakin tinggi rasio minyak jagung maka nilai $\mathrm{pH}$ sosis semakin tinggi. Soeparno (2005) dan Setiyono (2008) menyatakan bahwa apabila produk daging olahan yang bahan dasarnya dan bahan pendukungnya mempunyai nilai $\mathrm{pH}$ yang sama atau variasinya kecil atau besar maka akan menyebabkan produk daging olahan mempunyai $\mathrm{pH}$ yang sama atau variasinya kecil atau besar. Terdapat interaksi yang nyata antara metode pemasakan yang berbeda dengan rasio minyak yang berbeda pada nilai $\mathrm{pH}$ sosis $(\mathrm{P}<0,05)$. Temperatur pemasakan yang rendah pada vacuum steaming dan rasio minyak ikan kod yang semakin rendah atau rasio minyak jagung yang semakin tinggi diikuti dengan peningkatan nilai $\mathrm{pH}$ sosis.

Daya ikat air. Perlakuan pemasakan menunjukkan perbedaan yang nyata pada daya ikat air sosis $(P<0,05)$. Temperatur pemasakan yang lebih rendah pada vacuum steaming menyebabkan daya ikat air sosis $(53,36 \pm 1,10 \%)$ lebih tinggi dibandingkan dengan daya ikat air sosis yang dimasak

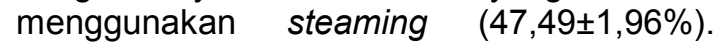
Temperatur yang tinggi pada steaming dibandingkan vacuum steaming menyebabkan banyaknya kadar protein yang

Tabel 2. Kualitas fisik sosis yang diformulasi dengan rasio minyak ikan kod dan minyak jagung yang berbeda dan diproses dengan metode pemasakan yang berbeda

(physical quality of sausages formulated with different ratio of cod oil and corn oil and processed with different cooking methods)

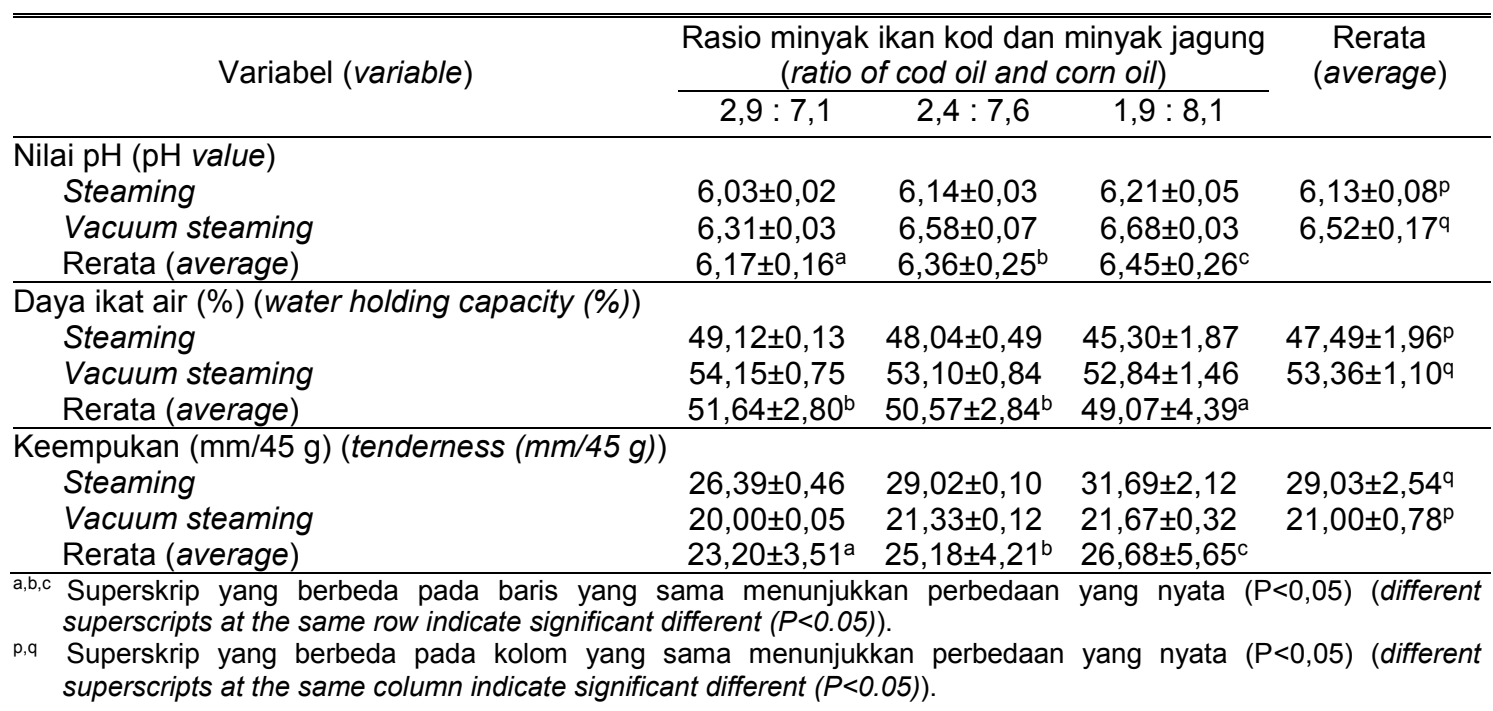


mengalami denaturasi sehingga menyebabkan turunnya daya ikat air sosis. Hasil penelitian ini sesuai dengan Lawrie dan Ledward (2005) dan Soeparno (2005) yang menyatakan bahwa suhu yang tinggi selama proses pemasakan akan menyebabkan terjadinya proses denaturasi protein dan banyak menurunkan kapasitas mengikat air. Widaningrum et al. (2008) dan Setiyono et al. (2013) menyatakan bahwa pemasakan secara vakum dapat mempertahankan kadar protein yang berperan dalam pengikatan air dalam suatu produk.

Rasio minyak menunjukkan perbedaan yang nyata pada daya ikat air sosis $(P<0,05)$, semakin tinggi rasio minyak ikan kod atau semakin rendah rasio minyak jagung maka daya ikat air sosis semakin tinggi. Hasil penelitian ini diduga karena pada jumlah yang sama minyak ikan kod mempunyai ukuran butiran lemak yang lebih kecil dibandingkan dengan minyak jagung sehingga membutuhkan protein yang lebih banyak untuk membentuk emulsi. Jumlah protein yang tinggi akan menyebabkan daya ikat air sosis menjadi semakin meningkat. Foegeding dan Lanier (1989); Declan et al. (1999); dan Soeparno (2005) menyatakan bahwa kemampuan mengikat air pada produk daging akan sesuai dengan kadar protein yang ada pada produk daging tersebut, semakin besar kadar proteinnya maka semakin besar pula daya mengikat air produk daging tersebut. Tidak terdapat interaksi yang nyata antara metode pemasakan yang berbeda dengan rasio minyak yang berbeda pada daya ikat air sosis.

Keempukan. Metode pemasakan yang berbeda menunjukkan perbedaan yang nyata pada keempukan sosis $(P<0,05)$. Temperatur pemasakan yang lebih rendah pada vacuum steaming menyebabkan keempukan sosis $(21,00 \pm 0,78 \mathrm{~mm} / 45 \mathrm{~g})$ lebih rendah dibandingkan dengan keempukan sosis yang dimasak menggunakan steaming $(29,03 \pm 2,54 \mathrm{~mm} / 45 \mathrm{~g})$. Bouchon et al. (2003) menyatakan bahwa temperatur pemasakan yang tinggi akan menyebabkan banyak rongga di dalam produk daging yang ditinggalkan oleh air yang menyebabkan produk daging tersebut porous sehingga keempukannya meningkat.

Rasio minyak yang berbeda menunjukkan perbedaan yang nyata pada keempukan sosis $(P<0,05)$, semakin rendah rasio minyak ikan kod atau semakin tinggi rasio minyak jagung maka keempukan sosis semakin tinggi. Hasil penelitian ini diduga karena pada jumlah yang sama ukuran butiran lemak minyak ikan kod lebih kecil dibandingkan dengan minyak jagung sehingga dapat membentuk emulsi yang lebih baik. Oleh karena itu rasio minyak ikan kod yang semakin meningkat menyebabkan sosis menjadi semakin kenyal. Barbutf (1992); Soeparno (2005); dan Setiyono (2008) menyatakan bahwa bahan produk daging yang empuk akan menghasilkan produk daging yang empuk pula.

Terdapat interaksi yang nyata antara metode pemasakan yang berbeda dengan rasio minyak yang berbeda $(P<0,05)$ pada keempukan sosis. Temperatur pemasakan yang lebih rendah pada vacuum steaming dibandingkan dengan steaming dan rasio minyak ikan kod yang semakin tinggi atau rasio minyak jagung yang semakin rendah diikuti dengan penurunan keempukan sosis.

\section{Asam lemak omega 3 dan omega 6 sosis}

Hasil uji asam lemak omega 3 dan omega 6 sosis daging sapi yang diformulasi dengan tiga macam rasio minyak ikan kod dan minyak jagung yang berbeda dan diproses dengan dua metode pemasakan yang berbeda disajikan pada Tabel 3 .

Hasil penelitian menunjukkan bahwa sosis yang mempunyai rasio asam lemak tidak jenuh omega 3 : omega 6 yang mendekati ideal adalah sosis dengan rasio minyak ikan kod dan minyak jagung 2,4 : 7,6 yang dimasak menggunakan vacuum steaming, yaitu mempunyai rasio $1: 5,29$. Pada saat pengukuran minyak ikan kod banyak mengandung asam lemak omega 3 yaitu sebesar 19,61\%, sedangkan minyak jagung banyak mengandung asam lemak omega 6 yaitu sebesar $46 \%$, sehingga rasio minyak ikan kod dan minyak jagung yang semakin tinggi masing-masing menyebabkan kenaikan asam lemak omega 3 dan omega 6 sosis. Kadar asam lemak omega 3 dan omega 6 yang lebih rendah pada steaming dibandingkan pada vacuum steaming diduga disebabkan karena temperatur pemasakan yang lebih tinggi pada steaming dibandingkan dengan vacuum steaming sehingga menurunkan kadar asam lemak omega 3 dan omega 6 sosis. Selama proses pemasakan terjadi proses oksidasi minyak atau lemak menjadi hidroperoksida, alkohol, keton, aldehid, dan asam lemak bebas, namun pemasakan secara vakum dapat 
Tabel 3. Kadar asam lemak omega 3 dan omega 6 dari kadar lemak sosis yang diformulasi dengan rasio minyak ikan kod dan minyak jagung yang berbeda dan diproses menggunakan metode pemasakan yang berbeda

(omega 3 and omega 6 fatty acids of fat content of sausages formulated with different ratio of cod oil and corn oil and processed by different cooking methods)

\begin{tabular}{|c|c|c|c|c|c|c|}
\hline \multirow[t]{3}{*}{ Asam lemak (\%) (fatty acids (\%)) } & \multicolumn{6}{|c|}{$\begin{array}{c}\text { Rasio minyak ikan kod dan minyak jagung (ratio of cod oil and } \\
\text { corn oil) }\end{array}$} \\
\hline & $2,9: 7,1$ & $2,4: 7,6$ & $1,9: 8,1$ & $2,9: 7,1$ & $2,4: 7,6$ & $1,9: 8,1$ \\
\hline & \multicolumn{3}{|c|}{ Steaming } & \multicolumn{3}{|c|}{ Vacuum steaming } \\
\hline $\begin{array}{l}\text { Asam lemak omega } 3 \text { (omega } 3 \text { fatty } \\
\text { acid) }\end{array}$ & 3,35 & 3,00 & 2,54 & 7,08 & 6,71 & 5,62 \\
\hline $\begin{array}{l}\text { Asam lemak omega } 6 \text { (omega } 6 \text { fatty } \\
\text { acid) }\end{array}$ & 29,95 & 32,14 & 33,58 & 33,05 & 35,52 & 37,53 \\
\hline $\begin{array}{l}\text { Rasio omega } 3 \text { : omega } 6 \text { (ratio of } \\
\text { omega } 3: \text { omega } 6 \text { ) }\end{array}$ & $1: 8,94$ & $1: 10,71$ & $1: 13,22$ & $1: 4,67$ & $1: 5,29$ & $1: 6,68$ \\
\hline
\end{tabular}

menghambat proses oksidasi lipid karena temperatur yang rendah dan absennya udara selama pemasakan (White, 1991; Melton et al., 1994; Tarzi et al., 2011; Amany et al., 2012).

Minyak ikan kod dan minyak jagung yang digunakan sebagai bahan penyusun sosis mempunyai bobot jenis dan melting point yang relatif rendah, bobot jenis dan melting point minyak ikan kod dan minyak jagung yaitu 0,920 dan $59^{\circ} \mathrm{F}$; dan 0,924 dan $60^{\circ} \mathrm{F}$ (Anonim, 2014), sehingga minyak ikan kod dan minyak jagung mudah teroksidasi selama proses pemasakan terutama pada steaming dibandingkan dengan vacuum steaming. Subtitusi lemak dengan minyak yang berasal dari hewan yang hidup di laut dan dari tanaman dalam pembuatan sosis frankfurters menghasilkan produk sosis yang lebih menyehatkan (Fernández-Martin et al., 2009; Marchetti et al., 2013). Inkorporasi minyak ikan dalam pembuatan sosis sudah diteliti baik dalam pembuatan sosis yang dibuat dengan cara fermentasi maupun sosis yang dibuat dengan cara dimasak (Muguerza et al., 2004; Valencia et al., 2006; Pelser et al., 2007; Marchetti et al., 2013). Andrés et al. (2009) cit. Marchetti et al. (2013) memformulasi sosis ayam low fat dengan squid oil menghasilkan profil asam lemak yang lebih baik dibandingkan dengan lemak sapi, dengan stabilitas dan kualitas produk yang baik.

\section{Kesimpulan}

Berdasarkan komposisi kimia, kualitas fisik, dan rasio asam lemak omega 3 dan omega 6 sosis, rasio minyak ikan kod dan minyak jagung sebesar 2,4 : 7,6 menunjukkan hasil yang paling baik. Metode pemasakan sosis menggunakan vacuum steaming menghasilkan kualitas sosis yang lebih baik dibandingkan menggunakan steaming. Terdapat interaksi antara rasio minyak ikan kod dan minyak jagung yang berbeda dengan metode pemasakan yang berbeda (steaming dan vacuum steaming) pada kadar air, kadar protein, $\mathrm{pH}$, dan keempukan sosis, namun tidak terdapat interaksi pada kadar lemak dan daya ikat air sosis.

\section{Daftar Pustaka}

Amany, M., M. Basuny, Shaker, M. Arafat, Azza and A. A. Ahmed. 2012. Vacuum frying : an alternative to obtain high quality potato chips and fried oil. Global Advanced Research J. 1: 019026 .

Anonim. 2012. Penyakit Tidak Menular. Buletin Jendela Data dan Informasi Kesehatan. Semester II. Kementerian Kesehatan, Jakarta.

Anonim. 2014. Liquids and Fluids - Specific Gravities - SG. Available at: www. TheEngineeringToolBox.com. Accessed 17 December 2014.

Anonim. 2015. Omega-3 dan Omega-6 untuk Kesehatan Jantung. Available at: www.mbrio-food.com/index1.php? view\&id=69\#. Vcj7YUmkfqC. Accessed 11 August 2015.

AOAC. 2005. Official Methods of Analysis. $18^{\text {th }}$ edn. Association of Official Analytical Chemist, Washington DC.

Barbutf, S. 1992. Poultry processing and product technology. Encyclopedia of Food Science and Technology, New York. 
Bouchon, P., J. M. Aguilera and D. L. Pyle. 2003. Structure oil-absorption relationships during deep-fat frying. J. Food Sci. 68: 2711-2716.

Bouton, P. E., P. V. Harris and W. R. Shorthose. 1971. Effect of ultimate $\mathrm{pH}$ upon the water holding capacity and tenderness of mutton. J. Food Sci. 36: 435-439.

Candogan, K. and N. Kolsarici. 2003. The effects of carrageenan and pectin on some quality characteristics of low fat beef frankfurters. Meat Sci. 64: 199203.

Choi, D. J. Han, H. Y. Kim, M. A. L. HyunWook and K. J. Y. Jeong. 2009. Characteristics of low-fat meat emulsion systems with pork fat replaced by vegetable oils and rice bran fiber. Meat Sci. 82: 266-271.

Declan, J. T., E. M. Desmond and D. J. Buckley. 1999. Eating quality of low fat beef burgers containing fat replacing functional blends. J. Food. Agric. Sci. 79: 507-516.

Dueik, V., P. Robert and P. Bouchon. 2010. Vacuum frying reduces oil uptake and improves the quality parameters of carrot crisps. Food Chem. 119: 11431149.

Elmadfa, I. and M. Kornsteiner. 2009. Fats and fatty acid requirement for adults. J. Ann. Nutr. Metab. 75: 55-56.

Fernández-Martin, F., I. López-López, S. Cofrades and $F$. Jiménez-Colmenero. 2009. Influence of adding sea spaghetti seaweed and replacing the animal fat with olive oil or a konjac gel on pork meat batter gelation. Potential protein/alginate association. Meat Sci. 83: 209-217.

Foegeding, E. A. and T. C. Lanier. 1989. The contribution of non-muscle proteins to texture of gelled muscle protein foods. In: Protein Quality and the Effect of Processing. R. D. Phllips and J. W. Finley (eds). Marcel Dekker, New York. Pp. 331-343.

Hamm, R. 1986. Functional properties of the myofibrillar system and their measurement. In: Muscle as Food. P. J. Bechtel (ed). Academic Press, New York. Pp. 135-199.
Krummel, D. A. 2008. Medical nutrition therapy in cardiovascular disease, in: Nutrition and diet therapy. $12^{\text {th }}$ edn Mahan, L. K. and S. Escott Stump (eds). Saunders Company, Philadelphia.

Lawrie, R. A. and D. A. Ledward. 2005. Meat science. $7^{\text {rd }}$ edn. CRC Press, Boca Ranton, New York.

Marchetti, L., S. C. Andrés and A. N. Califano. 2013. Textural and thermal properties of low-lipid meat emulsions formulated with fish oil and different binders. LWT - Food Sci. Tech. 51: 514-523.

Mariscal, M. and P. Bouchon. 2008. Comparison between atmospheric and vacuum frying of apple slices. Food Chem. 107: 1561-1569.

Martin, M. and J. Garden. 2004. The Art and Practice of Sausage Making. North Dakota State University Extension.

Melton, S. L., S. Jafar, D. Sykes and M. Trigiano. 1994. Review of stability measurements for frying oils and fried food flavor. J. American Oil Chemical Society. 71: 1301-1308.

Muchtadi, T. R. dan F. Ayustaningwarno. 2010. Teknologi Proses Pengolahan Pangan. Cetakan Ke-4. Alfabeta, Bandung.

Muguerza, E., D. Ansorena and I. Astiasarán. 2004. Functional dry fermented sausages manufactured with high levels of $\mathrm{n}-3$ fatty acids: nutritional benefits and evaluation of oxidation. J. Sci. Food Agric. 84: 1061-1068.

Pelser, W. M., J. P. H. Linssen, A. Legger and J. H. Houben. 2007. Lipid oxidation in n-3 fatty acid enriched Dutch style fermented sausages. Meat Sci. 75: 1-11.

Saguy, S. and D. Dana. 2003. Integrated approach to deep fat frying: Engineering, nutrition, health and consumer aspects. J. Food Engineering 56: 143-152.

Setiyono, E. Suryanto, Rusman, dan R. O. Sujarwanta. 2013. Pengaruh suhu pemasakan terhadap kualitas fisik, kimia, sensoris, dan mikrostruktur sosis daging sapi dengan penambahan lemak tidak jenuh yang diproses dengan teknologi vacuum frying. Laporan Hibah Penelitian Pascasarjana Fakultas Peternakan Universitas Gadjah Mada, Yogyakarta. 
Setiyono. 2008. Restrukturisasi daging sapi untuk pangan kesehatan : studi pada Ratus Norvegicus L. Disertasi Universitas Gadjah Mada, Yogyakarta.

Sheard, P. R., G. R. Nute and A. O. Chappel. 1998. The effect of cooking on the chemical composition of meat product with special reference to fat loss. J. Meat Sci. 49: 175-191.

SNI. 1995. SNI 01-3820-1995. Sosis daging. Badan Standardisasi Nasional, Jakarta.

SNI. 1998. SNI 01-3394-1998. Minyak jagung sebagai minyak makan. Dewan Standarisasi Nasional, Jakarta.

Soeparno. 2005. IImu dan Teknologi Daging. Cetakan ke-4, Gadjah Mada Press, Yogyakarta.

Steel, R. G. D. dan J. H. Torrie. 1993. Prinsip dan Prosedur Statistik. Suatu Pendekatan Biometrik. Diterjemahkan oleh M. Syah. PT. Gramedia Pustaka Utama, Jakarta.

Sudarmadji, S., B. Haryono, dan Suhardi. 1997. Prosedur Analisa untuk Bahan Makanan dan Pertanian. Penerbit Liberty, Yogyakarta.

Tarzi, B. G., A. Bassiri, M. Ghavami and M. Bamenoghadam. 2011. Process of optimization in vacuum frying of mushroom using response surface methodology. World Appl. Sci. J. 14: 960-966.
Troncoso, E., F. Pedreschi and R. N. Zuniga. 2009. Comparative study of physical and sensory properties of pre-treated potato slices during vacuum and atmospheric frying. Food Sci. Technol. 42: 187-195.

Valencia, I., D. Ansorena and I. Astiasarán. 2006. Stability of linseed oil and antioxidants containing dry fermented sausages: a study of the lipid fraction during different storage conditions. Meat Sci. 63: 269-277.

Valenzuela, A. and N. Morgado. 1999. Trans fatty acid isomers in human health and in the food industry. Biol. Res. 32.

Wan, R. W., A. S. Babji, A. Aminah, S. P. Foo and O. A. Malik. 2005. Effects of processing on nutrition and sensory qualities of beef burgers incorporated with palm fats. J. Nutr. 11: 165-175.

White, P. J. 1991. Methods of measuring changes in deep fat frying oils. Food Tech. 45: 75-79.

Widaningrum, N. Setyawan, dan D. A. Setyabudi. 2008. Pengaruh cara pembumbuan dan suhu penggorengan vakum terhadap sifat kimia dan sensori keripik buncis (Phaseolus radiatus) muda. Jurnal Pascapanen 5: 45-54.

Zhang, W., S. Xiao, H. Samaraweera, E. J. Lee and D. U. Ahn. 2010. Improving functional value of meat products. Meat Sci. 86: 15-31. 